\section{Hereditary neuropathy with liability to pressure palsies: a single-center experience in southern Brazil}

\author{
Paulo José Lorenzoni, Cláudia Suemi \\ Kamoi Kay, Cristiane Cavalet, Raquel \\ C. Arndt, Lineu Cesar Werneck, Rosana \\ Herminia Scola
}

Service of Neuromuscular Disorders, Division of Neurology, Department of Internal Medicine, Hospital de Clínicas, Universidade Federal do Paraná (UFPR), Curitiba, Brazil

\begin{abstract}
The spectrum of clinical and electrophysiological features in hereditary neuropathy with liability to pressure palsies (HNPP) is broad. We analyze a series of Brazilian patients with HNPP. Correlations between clinical manifestations, laboratory features, electrophysiological analyze, histological and molecular findings were done. In five cases, more than one episode occurred before diagnosis. Median nerve in the carpal tunnel at the wrist, ulnar nerve in its groove at the elbow, fibular nerve in the head of the fibula at the knee, radial nerve in its groove of the humerus and suprascapular nerve in its notch at the supraspinous fossa were found as focal neuropathies. One patient presented with persistent writer's cramp after ulnar nerve palsy. Nerve conduction studies showed focal neuropathy in all patients and concomitant generalized symmetrical neuropathy in eight patients. Molecular analysis of the PMP22 gene detected deletion of the 1.5-Mb fragment in all patients.
\end{abstract}

\section{Introduction}

The spectrum of clinical and electrophysiological features in hereditary neuropathy with liability to pressure palsies (HNPP) is broad and may range from clinically asymptomatic or subclinical to recurrent palsies and in some advanced cases, generalized neuropathies. . $^{1-4}$

HNPP has specific clinical and electrophysiological characteristics, but there are few studies describing their characteristics in a series of Brazilian patients to date. The aim of our study was to analyze a series of HNPP patients to contribute to better characterization of the disease in southern Brazil.

\section{Materials and Methods}

A retrospective analysis of 3828 patients who underwent electrophysiological analysis from 2004 to 2015 revealed 10 patients with a diagnosis of HNPP, according to three of the following obligatory criteria: typical clinical features, familial history, abnormal electrophysiological analysis and absence of other causes of neuropathy on follow-up at least one year after the diagnosis. Relevant data included age, age at onset (first episode of acute nerve palsy), gender, clinical manifestations, and other affected relatives. Characteristics of acute nerve palsy episodes and concomitance of generalized symmetric neuropathy were recorded. Cerebrospinal fluid (CSF) protein level was classified as normal $(<45 \mathrm{mg} / \mathrm{dL})$ or increased ( $\geq 45 \mathrm{mg} / \mathrm{dL}$ ).

Motor and sensory nerve conduction studies (NCS) were performed bilaterally using Neuropack 2 or M1 (NIHON KOHDEN) machines according to routine protocols. We considered all examined segments in the evaluation of conduction block (CB), defined as a reduction greater than $50 \%$ in proximal compared with distal potential amplitude associated with temporal dispersion. Needle electromyography (EMG) pattern was classified as normal, myopathic or denervated.

Nerve biopsy was stained histologically and histochemical reactions performed, according to standard procedures.

DNA was isolated from peripheral leucocytes using a modified phenol/chloroform method. The PMP22 gene was subjected to polymerase chain reaction-restriction fragment length polymorphism (PCR/RFLP) analysis, consisting of PCR, which produced a 3,6 kbp fragment, followed by restriction endonuclease digestion with $E c o R I$, according to standard procedures. Wild-type DNA produced fragments (3.2 and $0.4 \mathrm{kbp}$ ), whereas DNA from patients heterozygous for the mutation presented three fragments (3.6, 3.2 and $0.4 \mathrm{kpb})$ because, in the presence of the putative mutation (deletion of the $1.5-\mathrm{Mb}$ region in the PMP22 gene) the 3.6-kbp fragment is not cleaved into two fragments.

\section{Results}

The sample consisted of 10 patients from seven unrelated families (Table 1). HNPP was diagnosed before the identification of other affected family members in six patients.

Acute nerve palsy occurred in seven cases. In five cases, more than one episode occurred before diagnosis. A diagnosis was made during the first palsy episode in two cases and in the remaining three cases, a diagnosis was
Correspondence: Rosana Herminia Scola, Service of Neuromuscular Disorders, Division of Neurology, Department of Internal Medicine, Hospital de Clínicas, Universidade Federal do Paraná (UFPR), Rua General Carneiro 181/3 andar - 80060-900 Curitiba PR, Brazil.

E-mail: rosana.scola@hc.ufpr.br

Key words: Hereditary neuropathy with liability to pressure palsies; hereditary neuropathy; dystonia; writer's cramp; electrophysiological study.

Acknowledgements: supported by Fundação Araucária, CAPES and CNPq.

Contributions: PJL, design of the paper, conception of the paper, drafting the paper, data acquisition, analysis and interpretation, final approval; CSKK, data acquisition and analysis, critical revising, final approval; CC and RCA, data acquisition and analysis, revising, final approval; LCW, data interpretation, critical revising, final approval; RHS, conception of the paper, data acquisition and analysis, critical revising, final approval.

Conflict of interest: the authors declare no potential conflict of interest.

Received for publication: 4 July 2016 .

Revision received: 5 August 2016.

Accepted for publication: 8 August 2016.

This work is licensed under a Creative Commons Attribution NonCommercial 4.0 License (CC BYNC 4.0).

(C) Copyright P.J. Lorenzoni et al., 2016

Licensee PAGEPress, Italy

Neurology International 2016; 8:6677

doi:10.4081/ni.2016.6677

obtained before the palsy episode considering electrophysiological analysis and the presence of affected family members. Table 1 shows focal sites at first nerve palsy and recurrent episodes; three cases did not report any acute nerve palsy episodes. Concomitant generalized symmetric neuropathy was present in two cases (Table 1). One patient presented with writer's cramp (case 5).

NCS showed focal neuropathy (abnormal conduction velocities limited to entrapment or compression sites) in all patients and concomitant generalized symmetrical neuropathy in eight patients (Table 1). CB was observed into site of entrapment in case 7 (peroneal nerve). EMG revealed denervation findings in six patients and dystonic findings (concomitant activity of agonist and antagonist muscles during writing task) in case 5 (Table 1). CSF protein level was mildly increased $(57 \mathrm{mg} / \mathrm{dL})$ in one patient (Table 1). Sural nerve biopsy found tomacula in three cases (Table 1).

Molecular analysis of the PMP22 gene 
detected deletion of the 1.5-Mb fragment in all patients.

\section{Discussion and Conclusions}

Findings in our patients are, in general, similar to those previously described. ${ }^{2-5}$ Although in our cases, the clinical and electrophysiological phenotype was not homogeneous within the same family.

Some patients presented with an atypical spectrum of findings, which can occur in up to $56 \%$ of HNPP patients. ${ }^{3}$ In our patients, the peroneal and ulnar nerves were the most vulnerable, but they presented a higher frequency of radial nerve palsy than previously reported, including the site of first nerve palsy episode, as well as uncommon suprascapular nerve palsy (case 10).1,3,5,6 Suprascapular palsy was rarely reported associated with HNPP. Also, one patient (case 1) was previously reported due to recurrent episodes of swallowing dysfunction and three patients presented carpal tunnel syndrome as the main manifestation, which helps to confirm that cranial nerve palsy and chronic mononeuropathies are relevant in HNPP.7,8 In addition, one patient (case 5) presented clinical features of writer's cramp, which has persisted since his ulnar nerve palsy. Writer's cramp caused by HNPP was reported only once as a possible result of persistent compensation after nerve palsy. ${ }^{9} \mathrm{We}$ speculated that a similar mechanism, and maybe an aberrant reinervation, could be occurring in our patient, which allowed us to include HNPP as one more etiology causing writer's cramp.

NCS are usually characterized by a generalized demyelinating neuropathy with conduction abnormalities preferentially localized at common entrapment sites, similar to what we observed in our cases. ${ }^{3,4,6,8,10}$ Electrophysiological analysis detected three patients in affected families before acute nerve palsy had become apparent. CB on nerve entrapment sites was rarely observed in our study. CB seems to have a higher frequency when nerve palsy occurs in childhood, but this may be because NCS were performed closer to the nerve palsy episode. ${ }^{8}$ Indeed, we did not find studies comparing NCS features at acute episode and after long-term outcome. The difference between age at onset and at diagnosis in our patients suggests that $\mathrm{CB}$ is not often observed after long-term outcome of a nerve palsy episode; however, this feature is not restricted to HNPP because it can occur in immune-mediated neuropathies.

High CSF protein level and tomacula in the nerve biopsy may be useful in differential diagnosis when no affected family member is reported at first. However, these finding are not a specific marker for HNPP and they should be avoid if NCS can be followed by genetic analysis. $2,3,4,6$

The typical $1.5-\mathrm{Mb}$ deletion in the PMP22 gene is usually found in approximately 85 to $90 \%$ of patients with clinical evidence of HNPP.1,2,4,6 Although most analyses have been limited to populations from North America and Europe, this mutation has been reported in Brazil.7,10 Our study, despite being a small series, contributes to the idea that this mutation is also frequent in Brazilian patients.

Table 1. Characteristics of southern Brazilian hereditary neuropathy with liability to pressure palsies patients.

\begin{tabular}{|c|c|c|c|c|c|c|c|c|c|c|}
\hline & 1 & 2 & 3 & 4 & 5 & 6 & 7 & 8 & 9 & 10 \\
\hline Age (years) & 41 & 23 & 53 & 52 & 31 & 43 & 38 & 39 & 37 & 40 \\
\hline Age at onset (years) & 28 & 16 & $23 \S$ & $38 \S$ & 24 & 25 & 36 & $30 \S$ & 27 & 39 \\
\hline Gender & M & M & $\mathrm{F}$ & $\mathrm{F}$ & $\mathrm{M}$ & $\mathrm{F}$ & $\mathrm{M}$ & $\mathrm{M}$ & $\mathrm{M}$ & M \\
\hline Familial history* & + & + & + & + & - & + & + & + & - & - \\
\hline $\begin{array}{l}\text { Clinical manifestation }^{\circ} \\
\text { Acute nerve palsy }\end{array}$ & + & + & - & - & + & + & + & - & + & + \\
\hline $\begin{array}{l}\text { Site of first nerve palsy episode } \\
\text { Peroneal right } \\
\text { Radial right } \\
\text { Ulnar right } \\
\text { Suprascapular right } \\
\end{array}$ & $\begin{array}{l}+ \\
- \\
- \\
-\end{array}$ & $\begin{array}{l}- \\
+ \\
- \\
-\end{array}$ & $\begin{array}{l}- \\
- \\
-\end{array}$ & $\begin{array}{l}- \\
- \\
-\end{array}$ & $\begin{array}{l}- \\
- \\
+ \\
-\end{array}$ & $\begin{array}{l}- \\
+ \\
- \\
-\end{array}$ & $\begin{array}{l}- \\
+ \\
- \\
-\end{array}$ & $\begin{array}{l}- \\
- \\
-\end{array}$ & $\begin{array}{l}+ \\
- \\
- \\
-\end{array}$ & $\begin{array}{l}- \\
- \\
- \\
+\end{array}$ \\
\hline Number of different acute nerve palsies episodes & 3 & 1 & 0 & 0 & 2 & 3 & 2 & 0 & 2 & 2 \\
\hline $\begin{array}{l}\text { Site of focal neuropathy } \\
\text { carpal tunnel at the wrist } \\
\text { ulnar groove at the elbow } \\
\text { head of the fibula at the knee } \\
\text { radial groove of the humerus } \\
\text { suprascapular notch at the supraspinous fossa }\end{array}$ & $\begin{array}{l}- \\
+ \\
+ \\
+ \\
-\end{array}$ & $\begin{array}{l}- \\
- \\
- \\
+ \\
-\end{array}$ & $\begin{array}{l}+ \\
- \\
- \\
- \\
-\end{array}$ & $\begin{array}{l}+ \\
- \\
- \\
- \\
-\end{array}$ & $\begin{array}{l}- \\
+ \\
+ \\
- \\
-\end{array}$ & $\begin{array}{l}- \\
+ \\
+ \\
+ \\
-\end{array}$ & $\begin{array}{l}- \\
- \\
+ \\
+ \\
-\end{array}$ & $\begin{array}{l}+ \\
- \\
- \\
- \\
-\end{array}$ & $\begin{array}{l}+ \\
- \\
+ \\
- \\
-\end{array}$ & $\begin{array}{l}- \\
- \\
+ \\
- \\
+\end{array}$ \\
\hline Concomitant generalized symmetric neuropathy & - & - & - & + & - & + & - & - & - & - \\
\hline $\begin{array}{l}\text { Electrophysiological features } \\
\text { Focal abnormal NCV\# } \\
\text { Generalized abnormal NCV } \\
\text { Conduction block at entrapment } \\
\text { Denervated EMG }\end{array}$ & $\begin{array}{l}+ \\
+ \\
- \\
+\end{array}$ & $\begin{array}{c}+ \\
+ \\
- \\
\text { ND }\end{array}$ & $\begin{array}{l}+ \\
- \\
- \\
-\end{array}$ & $\begin{array}{l}+ \\
+ \\
- \\
-\end{array}$ & $\begin{array}{c}+ \\
- \\
- \\
+^{\wedge}\end{array}$ & $\begin{array}{l}+ \\
+ \\
- \\
-\end{array}$ & $\begin{array}{l}+ \\
+ \\
+ \\
+\end{array}$ & $\begin{array}{l}+ \\
+ \\
- \\
+\end{array}$ & $\begin{array}{l}+ \\
+ \\
- \\
+\end{array}$ & $\begin{array}{l}+ \\
+ \\
- \\
+\end{array}$ \\
\hline $\begin{array}{l}\text { Laboratorial analysis } \\
\text { Increased CSF protein }\end{array}$ & - & $\mathrm{ND}$ & ND & + & ND & - & ND & ND & ND & ND \\
\hline $\begin{array}{l}\text { Nerve biopsy } \\
\text { Tomacula } \\
\text { Onion bulbs } \\
\text { Axonal loss } \\
\text { Reduction of large myelinated fiber }\end{array}$ & $\begin{array}{l}+ \\
+ \\
+ \\
-\end{array}$ & $\begin{array}{l}\text { ND } \\
\text { ND } \\
\text { ND } \\
\text { ND }\end{array}$ & $\begin{array}{l}\text { ND } \\
\text { ND } \\
\text { ND } \\
\text { ND }\end{array}$ & $\begin{array}{l}+ \\
- \\
+ \\
-\end{array}$ & $\begin{array}{l}\text { ND } \\
\text { ND } \\
\text { ND } \\
\text { ND }\end{array}$ & $\begin{array}{l}- \\
- \\
- \\
+\end{array}$ & $\begin{array}{l}+ \\
- \\
- \\
-\end{array}$ & $\begin{array}{l}\text { ND } \\
\text { ND } \\
\text { ND } \\
\text { ND }\end{array}$ & $\begin{array}{l}\text { ND } \\
\text { ND } \\
\text { ND } \\
\text { ND }\end{array}$ & $\begin{array}{l}\text { ND } \\
\text { ND } \\
\text { ND } \\
\text { ND }\end{array}$ \\
\hline
\end{tabular}

F, female; M, male; +, present; - absent; ND, not done; NCS, nerve conduction study; EMG, needle electromyography; CSF, cerebrospinal fluid. *Possible affected family members; ${ }^{\circ}$ mainly presentation; \#abnormal conduction velocities limited to entrapment or compression sites; §was considered the time of the focal neuropathy diagnosis because did not occur episode of acute nerve palsy in these patients; ^ associated with dystonic muscle findings. 


\section{References}

1. van Paassen BW, van der Kooi AJ, van Spaendonck-Zwarts KY, et al. PMP22 related neuropathies: Charcot-Marie-Tooth disease type $1 \mathrm{~A}$ and hereditary neuropathy with liability to pressure palsies. Orphanet J Rare Dis 2014;9:38.

2. Meretoja P, Silander K, Kalimo H, et al. Epidemiology of hereditary neuropathy with liability to pressure palsies (HNPP) in south western Finland. Neuromuscul Disord 1997;7:529-32.

3. Luigetti M, Del Grande A, Conte A, et al. Clinical, neurophysiological and pathological findings of HNPP patients with 17p12 deletion: a single-centre experience. $\mathrm{J}$
Neurol Sci 2014;341:46-50.

4. Mouton P, Tardieu S, Gouider R, et al. Spectrum of clinical and electrophysiologic features in HNPP patients with the 17p11.2 deletion. Neurology 1999;52:14406.

5. Verhagen WIM, Gabreels-Festen AAWM, van Wensen PJM, et al. Hereditary neuropathy with liability to pressure palsies: a clinical, electroneurophysiological and morphological study. J Neurol Sci 1993;116:176-84.

6. Li J, Parker B, Martyn C, et al. The PMP22 gene and its related diseases. Mol Neurobiol 2013;47:673-98.

7. Lorenzoni PJ, Scola RH, Cardoso J, et al. Swallowing dysfunction in hereditary neuropathy with liability to pressure palsies.
Arq Neuropsiquiatr 2008;66:898-900.

8. Chrestian N, McMillan H, Poulin C, et al. Hereditary neuropathy with liability to pressure palsies in childhood: case series and literature update. Neuromuscul Disord 2015;25:693-8.

9. Straube A, Mai N, Walther E, Mayer M. Persisting "writer's cramp" as a result of compensation of a temporary palsy due to a hereditary neuropathy with liability to pressure palsies. Mov Disord 1996;11:5769.

10. Oliveira AP, Pereira RC, Onofre PT, et al. Clinical and neurophysiological features of the hereditary neuropathy with liability to pressure palsy due to the $17 \mathrm{p} 11.2$ deletion. Arq Neuropsiquiatr 2016;74:99-105. 